\title{
Effect of Explants and Low Cost Medium on Morphogenic Response of Aerial Stem and Rhizome Bud Explants of Turmeric (Curcuma longa L.) for Plant Regeneration
}

\author{
H.F.L. Upendri ${ }^{*}$ a and Thayamini H.Seran ${ }^{b}$ \\ Department of Crop Science, Faculty of Agriculture, Eastern University, Chenkalady, Sri Lanka \\ alakmaupendri19931109@gmail.com, bthayaminis@esn.ac.lk
}

Keywords: Curcuma longa L, rhizome bud, aerial stem, embryonic response, plant regeneration

\begin{abstract}
This study was done to select suitable explants and low cost medium for plant regeneration of turmeric. Therefore, the different explants were excised from the aerial stems and rhizome buds and surface sterilized. The sterilized explants were cultured on MS medium fortified with $2.0 \mathrm{mg} / 1$ BAP. From the survived aerial stem explants, $0.5 \mathrm{~cm}$ long vertical half of the aerial stem explants exhibited somatic embryogenic response (69.7\%). The highest morphogenic response (74\%) of shoot bud initiation was observed from the top slice of the surviving rhizome bud explants. Further, Yara Mila complex fertilizer, which is an ideal granular fertilizer mixture, was used as an alternative to MS medium. Three different concentrations of Yara Mila complex fertilizer (1.0, 3.0, and 5.0 g/1 ) supplemented with $2.0 \mathrm{mg} / 1 \mathrm{BAP}$ each were tested with the MS medium fortified with $2.0 \mathrm{mg} / \mathrm{l} \mathrm{BAP}$ (control treatment) for in vitro establishment from aerial stem explants and top slice of the rhizome bud explants. Both explants were surface sterilized and cultured on MS medium and different concentrations of Yara Mila complex fertilizer fortified with $2.0 \mathrm{mg} / \mathrm{l} \mathrm{BAP}$. From the survived explants, aerial stem explants exhibited somatic embryogenic response $(69.7 \%)$ and shoot bud initiation (74\%) on normal MS media. The higher performances were observed in $1.0 \mathrm{~g} / 1$ concentration of complex fertilizer incorporated medium with $51 \%$ embryogenic response from the aerial stem explants and $52.3 \%$ shoot bud formation response from the top slice of the rhizome bud. The cost of $1 \mathrm{~kg}$ complex fertilizer was Rs. 182. It could be concluded that complex fertilizer is a cost effective alternative medium for MS medium for in vitro propagation reducing the cost of the substituted ingredients by $99.87 \%$ in the tissue culture of turmeric.
\end{abstract}

\section{Introduction}

Turmeric (Curcuma longa L.) is a tropical herb belonging to the family Zingiberaceae. It is one of the spice crops grown in Sri Lanka. It is greatly valued plant because of its underground rhizomes. Turmeric powder from rhizomes is utilized as a spice, herbal medicine, dyeing agent and cosmetic [1]. Turmeric is propagated vegetatively through underground rhizomes. Conventional vegetative propagation of turmeric has a low rate of multiplication [2]. Further, rhizome of turmeric has a dormancy period and they sprout during monsoon only [3]. But, in vitro culture technique is an alternative method to obtain large number of healthy plant materials for commercial cultivation. In vitro culture technique largely depends on use of Murashige and Skoog (MS) nutrient medium [4] with plant growth regulators. BAP is used for shoot bud induction in the cultured explants of turmeric [5] and ginger [6-7].

The rhizome bud explants induced new shoot buds and roots in $3 \mathrm{mg} / 1 \mathrm{BAP}$ with $0.5 \mathrm{mg} / 1 \mathrm{NAA}$ medium which led to produce plantlets via organogenesis in ginger [7]. Embryonic response in the aerial stem explants was enhanced with the increase in BAP concentration from $1.0 \mathrm{mg} / 1$ to $2.0 \mathrm{mg} / 1$ [8]. [3] performed in vitro propagation through callus induction from rhizome buds and shoot tips of C. longa L. [9] stated that a high frequency of in vitro plantlets was achieved from fresh sprouting rhizome bud of $C$. longa L. on semisolid culture media. And also [10] studied callus induction and in vitro multiplication of turmeric by using rhizome buds and shoot tips of $C$. longa L. on MS medium. Hence, type of explants and culture medium play a significant role on in vitro propagation of turmeric through organogenesis or somatic embryogenesis directly or indirectly. 
For plant propagation, commercial application of plant tissue culture techniques is limited as a result of high production cost [11] than the conventional methods. However, there are ways to reduce the production cost for large scale plant production. [12] stated that in vitro culture medium requires chemicals which are often very expensive. [13] reported that modification in the nutrient medium to reduce the cost is needed for obtaining vigorous shoot growth. Thus, low cost culture medium is useful and convenient to produce disease-free plant materials for the small and large scale cultivators. [14] stated that optimal concentration of Hydro ${ }^{\circledR}$ Agri's fertilizer needs for plant regeneration of the cassava but higher rate of fertilizer is toxic to the plant tissues. [15] revealed the potential for developing a low cost micro propagating protocol for local bananas in Kenya. Therefore, the objective of this study was to develop a cost effective basal medium replacing macronutrients, micronutrients and iron sources of MS medium for turmeric plant multiplication. Yara Mila complex is a popular chemical fertilizer mixture $(12: 11: 18 \mathrm{~N}: \mathrm{P}: \mathrm{K}+3 \mathrm{MgO}+8 \mathrm{~S}+$ trace elements) for soil application and it is an ideal granular fertilizer. Hence, it is necessary to establish low cost culture medium with locally available fertilizers as alternative nutrient sources for in vitro propagation of turmeric using suitable explants.

\section{Materials and Methods}

This study was conducted at the Tissue Culture Laboratory of the Department of Crop Science, Faculty of Agriculture, Eastern University, Sri Lanka in 2019. Rhizomes with buds and two months old aerial shoots of turmeric plants were collected from field grown Sri Lankan local variety and used as the source of explants in this study. They were rinsed thoroughly in running tap water for 1 hour followed by distilled water. Rhizomes were treated with $2 \mathrm{~g} / \mathrm{l}$ Captan and then all the explants were sprayed with $70 \%$ alcohol for 30 seconds. Aerial shoot parts and rhizome bud pieces were immersed in $20 \%$ Clorox $^{\mathrm{TM}}$ and $25 \%$ Clorox $^{\mathrm{TM}}$ (Sodium hypochlorite, $5.25 \%$ active ingredient) respectively with 3 drops of tween 20 for 20 minutes. Subsequently explants were rinsed off 3 times with distilled water to remove traces of disinfectants and transferred to the laminar air floor hood with sterilized distilled water.

\section{Experiment 1}

This experiment was carried out to select suitable type of explants for in vitro propagation of turmeric from rhizome buds and aerial stem explants. Healthy turmeric plant parts and rhizome buds were sterilized as mentioned above and different types of explants were aseptically excised namely vertical segments of aerial stem at base $(0.5 \mathrm{~cm}, 1.0 \mathrm{~cm}$ long $), 2 \mathrm{~mm}$ thickness different slices of the aerial stem $\left(1^{\text {st }}\right.$ slice was taken from the bottom portion of the aerial stem and $2^{\text {nd }}$ slice was taken from the just above the ground level), white portion of inner stem (1.0 cm long) (Fig. 1), intact rhizome bud, slices of rhizome bud (top, middle and bottom) and vertical half of rhizome bud (Fig. 2) with the flame sterilized scalpel and forceps. They were placed in Murashige and Skoog (MS) medium (1962) with 3\% sucrose, $0.8 \%$ agar and $2.0 \mathrm{mg} / \mathrm{l}$ BAP for initial establishment. The culture bottles were sealed with parafilm strips and labeled properly. Then explants containing culture vessels were incubated at $25 \pm 2^{\circ} \mathrm{C}$ under white fluorescent light, in photoperiod of 16 hours light and 8 hours dark with the intensity of $2000-2500$ lux and $50 \%$ humidity was maintained and observation was made at regular intervals. This experiment was laid out in complete randomized design and repeated thrice. 


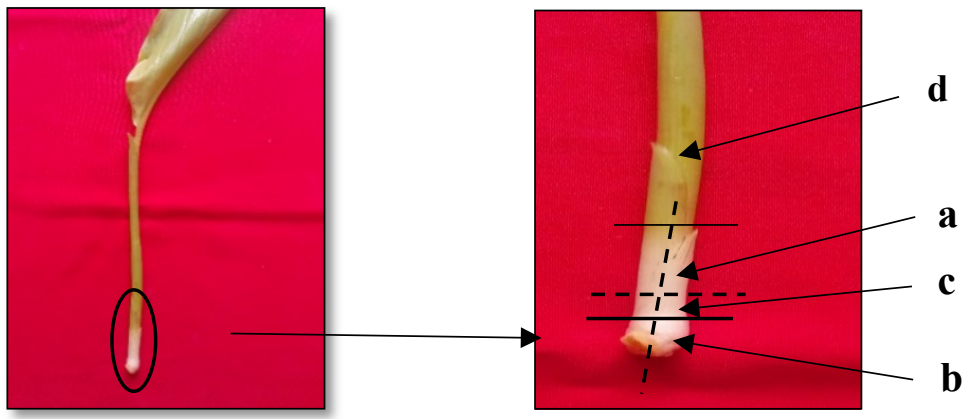

Figure 1. Aerial stem explants used in this study: a) Vertical segment of aerial stem at base $(0.5 \mathrm{~cm}$, $1.0 \mathrm{~cm}$ long $),$ b) $1^{\text {st }}$ slice of aerial stem $(2 \mathrm{~mm}$ thickness $\left.), \mathrm{c}\right) 2^{\text {nd }}$ slice of aerial stem $(2 \mathrm{~mm}$ thickness), d)White portion of inner stem (1.0 cm long)

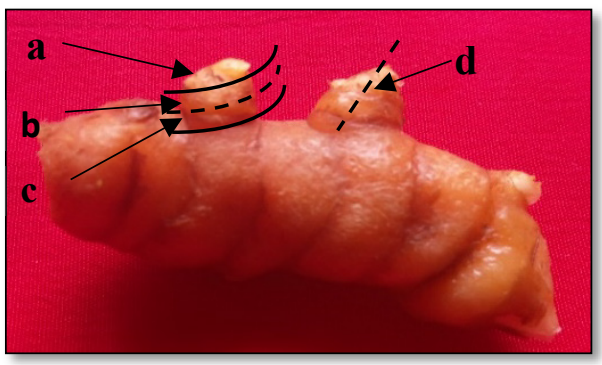

Figure 2. Rhizome bud explants used in this study: a) Top slice of rhizome bud, b) Middle slice of rhizome bud, c) Bottom slice of rhizome bud, d) Vertical half of rhizome bud

\section{Experiment 2}

Sterilized top slices of rhizome buds and also vertical segments $(0.5 \mathrm{~cm}$ long $)$ of aerial stems were used in this experiment to select the best concentration of Yara Mila complex replacing nutrient sources of MS medium for in vitro propagation. The basal medium used for the culture was MS medium with $3 \%$ sucrose and $0.8 \%$ agar. For preparation of alternative nutrient media, 3\% sucrose and $0.8 \%$ agar were added to each concentration of Yara Mila solutions as indicated in Table 1. Plant growth hormone, $2.0 \mathrm{mg} / 1 \mathrm{BAP}$ was also added to the culture medium. Yara Mila complex is an ideal granular fertilizer which contains $12 \% \mathrm{~N}, 11 \% \mathrm{P}_{2} \mathrm{O}_{5}, 18 \% \mathrm{~K}_{2} \mathrm{O}, 8 \% \mathrm{~S}, 2.9 \% \mathrm{MgO}, 0.2 \% \mathrm{Fe}, 0.02 \%$ $\mathrm{Mn}, 0.015 \% \mathrm{~B}, 0.02 \% \mathrm{Zn}$ and other trace elements in balanced amounts. For preparing different concentrations of Yara Mila nutrient solutions of $1.0 \mathrm{~g} / 1,3.0 \mathrm{~g} / 1$ and $5.0 \mathrm{~g} / \mathrm{l}$, each amount of locally available Yara Mila complex fertilizer $(12: 11: 18 \mathrm{~N}: \mathrm{P}: \mathrm{K}+3 \mathrm{MgO}+8 \mathrm{~S}+$ trace elements) granular from Unipower (Pvt) Ltd, Sri Lanka were dissolved in distilled water as an alternative source of MS nutrients. The sterilized explants were aseptically excised as top slice of the rhizome bud and $0.5 \mathrm{~cm}$ long vertical half of the aerial stem at base and cultured on MS medium and also Yara Mila alternative nutrient media with $2.0 \mathrm{mg} / 1 \mathrm{BAP}$. The culture vessels containing explants were incubated at $25 \pm 2^{\circ} \mathrm{C}$ under white fluorescent light. Photoperiod of $16 \mathrm{hrs}$ light and $8 \mathrm{hrs}$ dark with the intensity of $2000-$ 2500 lux was maintained.

Table 1. The different culture media used in this experiment

\begin{tabular}{cc}
\hline Treatment code & Culture media \\
\hline M1 & MS basal medium $+2.0 \mathrm{mg} / 1 \mathrm{BAP}$ \\
M2 & $1.0 \mathrm{~g} / 1$ complex fertilizer $+2.0 \mathrm{mg} / 1 \mathrm{BAP}$ \\
M3 & $3.0 \mathrm{~g} / 1$ complex fertilizer $+2.0 \mathrm{mg} / 1 \mathrm{BAP}$ \\
$\mathrm{M} 4$ & $5.0 \mathrm{~g} / \mathrm{l}$ complex fertilizer $+2.0 \mathrm{mg} / 1 \mathrm{BAP}$ \\
\hline
\end{tabular}


The observation was made on response of the cultured explants on different media after incubation. After six weeks of culture, the explants were transferred to same fresh medium. This experiment was laid out in complete randomized design and repeated three times.

\section{Statistical and Cost Analysis}

The percentages of explants showing morphogenic response and shoot bud formation were recorded at weekly intervals. The data obtained were subjected to analysis of variance (ANOVA) using SAS 9.1.3 portable version. The treatment means were compared using Duncan's multiple range test at 5\% significant level. The current market prices of the conventional and the alternative sources of nutrient salts were obtained. Based on the quantities used per liter of the culture media, the cost of each compound was calculated. Differences in cost between the conventional and alternative nutrient sources were then determined.

\section{Results and Discussion}

\section{Experiment 1}

\section{Aerial stem explants}

This experiment was carried out to determine the most suitable and responsive type of explant for in vitro propagation of turmeric from the both aerial stem and underground rhizome bud explants. Results obtained in this experiment had significant influence $(P<0.0001)$ for survival rate and morphogenic response with different explants (Table 2). High survival rate was obtained from the treatment with $1.0 \mathrm{~cm}$ long vertical half of the aerial stem explants and $2^{\text {nd }}$ slice of the aerial stem explants performing $58.7 \%$ survival rate. The least survival rate of $21 \%$ was recorded from the middle slice of the rhizome bud explants.

Table 2. Morphogenic response of different explants cultured on MS medium supplemented with $2.0 \mathrm{mg} / 1 \mathrm{BAP}$ at 5 weeks of culture

\begin{tabular}{|c|c|c|c|}
\hline $\begin{array}{l}\text { Treatment } \\
\text { code }\end{array}$ & Type of explants* & $\begin{array}{l}\text { Survival } \\
\%\end{array}$ & $\begin{array}{l}\text { \Morphogenic } \\
\text { response \% }\end{array}$ \\
\hline E1 & Vertical half of stem (1.0 cm long) & $58.7 \pm 4.3^{\mathrm{a}}$ & $28.3 \pm 6.0^{\mathrm{c}}$ \\
\hline $\mathbf{E 2}$ & Vertical half of stem $(0.5 \mathrm{~cm}$ long $)$ & $42.0 \pm 4.0^{\mathrm{bc}}$ & $69.7 \pm 2.7^{\mathrm{a}}$ \\
\hline $\mathbf{E 3}$ & $1^{\text {st }}$ slice of stem & $54.3 \pm 4.3^{\mathrm{ab}}$ & $00.0 \pm 0.0^{\mathrm{d}}$ \\
\hline $\mathbf{E 4}$ & $2^{\text {nd }}$ slice of stem & $58.7 \pm 4.3^{\mathrm{a}}$ & $00.0 \pm 0.0^{\mathrm{d}}$ \\
\hline E5 & White portion of inner stem ( $1.0 \mathrm{~cm}$ long $)$ & $54.3 \pm 4.3^{\mathrm{ab}}$ & $00.0 \pm 0.0^{\mathrm{d}}$ \\
\hline E6 & Intact bud $(1.0 \mathrm{~cm}$ long $)$ & $54.3 \pm 4.3^{\mathrm{ab}}$ & $61.7 \pm 7.3^{\mathrm{ab}}$ \\
\hline E7 & Vertical half of bud ( $1.0 \mathrm{~cm}$ long) & $33.7 \pm 4.3^{\mathrm{cd}}$ & $51.7 \pm 8.4^{\mathrm{b}}$ \\
\hline E8 & Top slice of intact bud & $50.3 \pm 7.2^{\mathrm{ab}}$ & $74.0 \pm 3.8^{\mathrm{a}}$ \\
\hline E9 & Middle slice of intact bud & $21.0 \pm 4.0^{\mathrm{d}}$ & $00.0 \pm 0.0^{\mathrm{d}}$ \\
\hline E10 & Bottom slice of intact bud & $29.3 \pm 4.3^{\mathrm{cd}}$ & $00.0 \pm 0.0^{\mathrm{d}}$ \\
\hline & F test & $\mathrm{P}<0.0001$ & $\mathrm{P}<0.0001$ \\
\hline
\end{tabular}

\footnotetext{
*Stem explants were excised from the aerial stems at the base and bud explants were taken from the rhizome bud.

TData based on the availability of surviving explants cultured in the medium.

Values represent means \pm standard error of the replicates. Means followed by the same letter in each column are not significantly different according to Duncan's Multiple Range Test at 5\% significant level
}

Among the slices of aerial stem (E3 and E4) and underground rhizome explants (E9 and E10), survivability was remarkably higher $(\mathrm{P}<0.05)$ in the aerial stem explants than the rhizome bud explants. In general, the rhizome buds are underground parts and contact with the soil. [16] stated that direct source of explants from field grown plants is commonly considered as one of the key factors for the establishments of cultures successfully under in vitro conditions. According to the 
results of Table 2, survival rate was significantly different $(\mathrm{P}<0.05)$ between $0.5 \mathrm{~cm}$ and $1.0 \mathrm{~cm}$ long vertical half of the aerial stem explants at base. Survivability of $1.0 \mathrm{~cm}$ long vertical half of the aerial stem explant was higher than $0.5 \mathrm{~cm}$ long vertical half of the aerial stem because the smaller explants are more likely to be damaged during handling and [17] reported that the larger explants probably has more nutrient reserves and endogenous plant growth regulators to sustain the culture. Further [18] stated that survival percentage of the cultured explants at $0.5 \mathrm{~cm}$ length was low because of browning of the explants.

Although $0.5 \mathrm{~cm}$ long vertical half of the aerial stem explant has lower survival percentage than $1.0 \mathrm{~cm}$ long vertical half of the aerial stem explant, smaller explant quickly responded to MS medium fortified with $2.0 \mathrm{mg} / \mathrm{l} \mathrm{BAP}$ within 2 weeks of culture. There was a significant effect on the morphogenic response of different explants $(\mathrm{P}<0.0001)$ as indicated in Table 2 and the $0.5 \mathrm{~cm}$ long explants responded $69.7 \%$ after 5 weeks of culture and $1.0 \mathrm{~cm}$ long explant responded $28.3 \%$ (Fig. 3). Further it was noted that vertical half of the aerial stem explant resulted transparent white (glossy) colour, globular and heart shape embryo like structure after 4 weeks and in some explants, enlarged sheaths were observed after 2 weeks and it was whitish green in colour. The morphological characters of the embryo formation are very clear in small $0.5 \mathrm{~cm}$ long explant than $1.0 \mathrm{~cm}$ long explant. MS medium fortified with $2.0 \mathrm{mg} / \mathrm{l} \mathrm{BAP}$ has a tendency to cell division and bud proliferation resulting in the shoot formation [19] and somatic embryogenic response in ginger was observed with increasing BAP concentration from $1.0 \mathrm{mg} / 1$ to $2.0 \mathrm{mg} / \mathrm{l}$ [8]. Juvenile parts of plant are generally responsive to somatic embryogenesis or regeneration [20]. Formation of somatic embryo at $25 \pm 2{ }^{\circ} \mathrm{C}$ and 16/8 $\mathrm{h}$ light and dark cycle was also achieved on saffron [21].

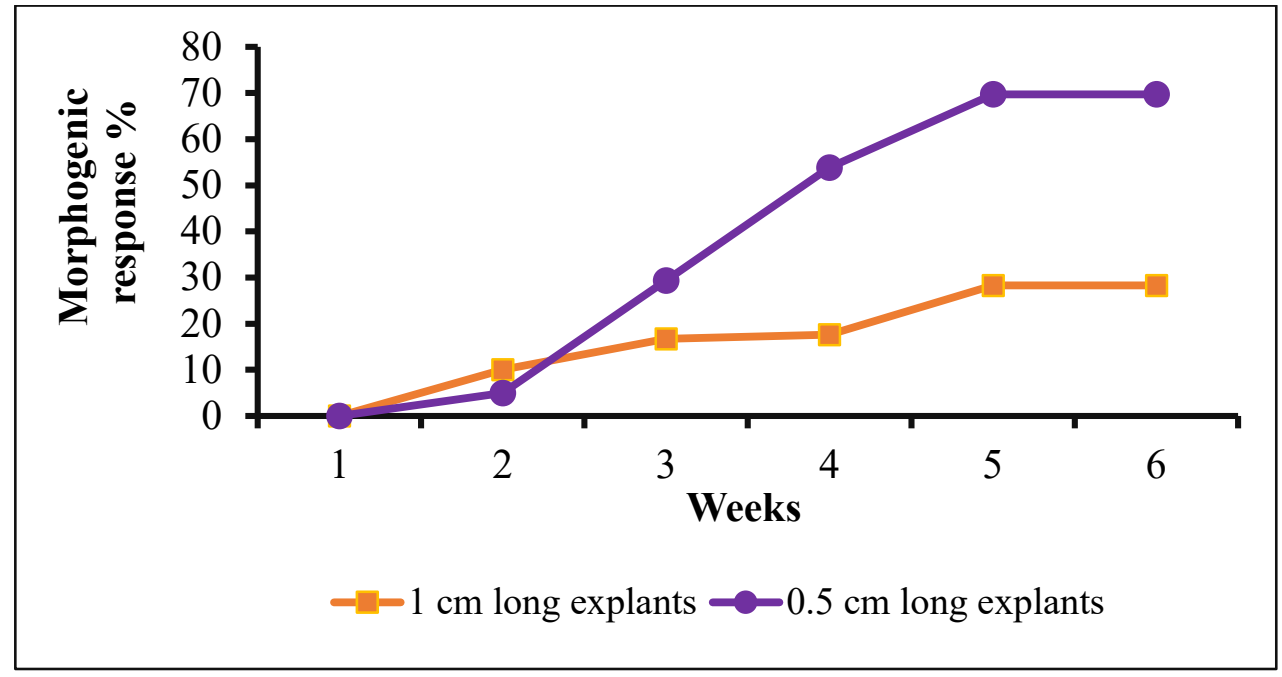

Figure 3. Morphogenic response percentage of vertical half of the aerial stem explants cultured on MS medium at weekly intervals (Data based on availability of surviving explants)

According to the data presented in Table 2, white colour portion of the inner stem had no any response after 5 weeks and further. But in vitro propagation of ginger using in vitro aerial stem (pseudostem) explants was reported by [22]. Slices of the aerial stem explants also had no any morphogenic response to the medium and there was no significant difference $(\mathrm{P}<0.05)$ between survivability of those explants. Low survivability was shown by the $1^{\text {st }}$ slice of the aerial stem as it is contacted with ground level and soil. The morphogenic response of the explants is in contrast with [23] who stated response of the stem base of $C$. longa and C. mangga because of the existence of a meristematic area in the basal portion from which the leaves and the roots were formed.

\section{Rhizome bud explants}

The responding pattern of different explants was significantly different $(\mathrm{P}<0.0001)$ as shown in Table 2. Intact rhizome bud had $61.7 \%$ of significantly higher $(\mathrm{P}<0.05)$ response than the vertical half of bud and initiated whitish green colour buds after 2 weeks which was elongated performing green 
colour two shoot buds at 5 weeks of stage. The vertical half of the rhizome bud had significantly lower $(\mathrm{P}<0.05)$ survival rate of $33.7 \%$ than intact rhizome bud explants. The top slice of the rhizome bud had remarkably highest $(\mathrm{P}<0.05)$ morphogenic response compared to other rhizomatous bud explants as it contains an active meristem. White colour clump of four shoot buds were observed after 4 weeks from the top slice of the rhizome bud. The multiple shoot buds are generally obtained in the presence of BAP used in the culture media that cytokinin induces shoot buds [24]. The vertical half of the bud showed elongated translucent white colour meristematic top growing towards upside. These results are in agreement with [25] who reported that sectioned buds produced shoots from each explant.

According to the results of Table 2, bottom slice of rhizome bud and middle slice of rhizome bud had significantly lower $(\mathrm{P}<0.05)$ survival rate than top slices of the rhizome bud explant. Intact rhizome bud also had significantly higher $(\mathrm{P}<0.05)$ survival rate than middle and bottom slice of rhizome bud as it is a larger explant and containing more nutrients to sustain the culture. Rhizome bud explants are underground part of turmeric. Hence, in vitro multiplication of aseptic culture is not easy due to the presence of pathogen on rhizome explants. Rhizomatic bud of turmeric have been utilized by [26-29] and they reported rhizomatous bud as a best explant for shoot induction. BAP strongly improved shoot multiplication in C. longa [30].

\section{Experiment 2}

\section{Aerial stem explants}

The different concentrations of Yara Mila complex fertilizer and normal MS medium were significantly influenced $(\mathrm{P}<0.0001)$ for the embryonic response of the vertical half $(0.5 \mathrm{~cm}$ long $)$ of the aerial stem explants (Fig. 4). M1 medium (normal MS medium with $2.0 \mathrm{mg} / \mathrm{l} \mathrm{BAP}$ as a control) showed higher embryonic response (70\%) than the other treatments after 5 weeks of culture and also transparent, white colour globular and heart shape somatic embryos like structures were observed (Fig. 5A). Globular somatic embryos regularly arranged were noted in other plants [31]. However, there was no remarkable variation $(\mathrm{P}<0.05)$ between $\mathrm{M} 1$ and $\mathrm{M} 2$ media in performing percentage of somatic embryos like structures from the vertical half of the aerial stem explants after 5 weeks (Fig. 5C).

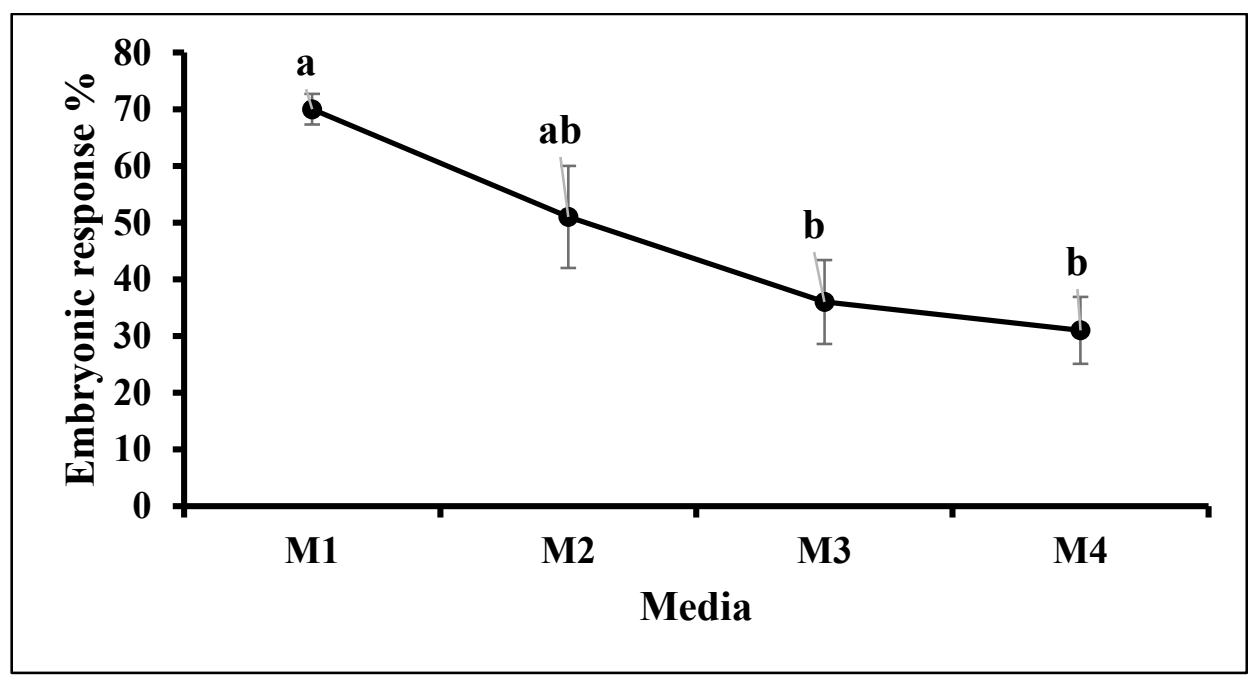

M1 : MS medium $+2.0 \mathrm{mg} / \mathrm{l} \mathrm{BAP}$

$\mathrm{M} 3: 3.0 \mathrm{~g} / \mathrm{l}$ complex fertilizer $+2.0 \mathrm{mg} / \mathrm{BAP}$
M2: $1.0 \mathrm{~g} / 1$ complex fertilizer $+2.0 \mathrm{mg} / \mathrm{l} \mathrm{BAP}$ M4 : $5.0 \mathrm{~g} / 1$ complex fertilizer $+2.0 \mathrm{mg} / 1 \mathrm{BAP}$

Figure 4. Embryonic response of the aerial stem explants cultured in different media after 5 weeks of culture

[Data based on the availability of surviving explants. Means with the same letter in each column are not significantly different according to Duncan's Multiple Range Test at 5\% significant level]. 


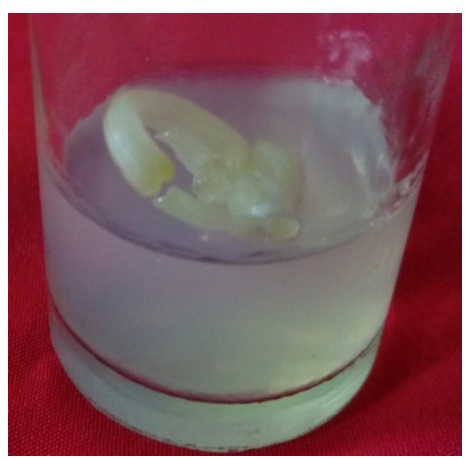

a

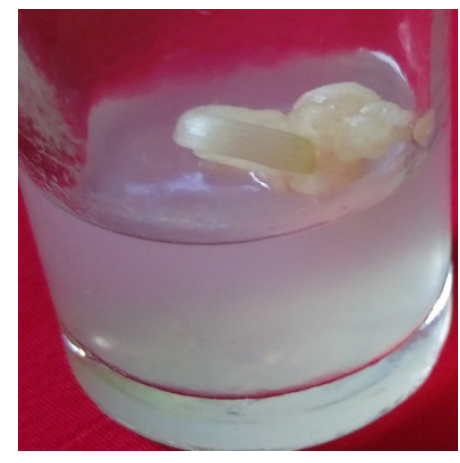

b

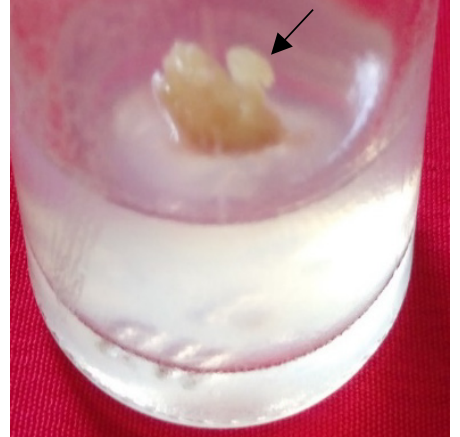

c

Figure 5. Somatic embryogenic response of aerial stem explants cultured in different media: a) Somatic embryogenic response of $0.5 \mathrm{~cm}$ long vertical half of aerial stem cultured on MS medium at $2^{\text {nd }}$ week and b) at $4^{\text {th }}$ week, c) $1.0 \mathrm{~g} / 1$ Yara Mila complex at earlier stage (Arrow: somatic embryo like structure)

M3 medium resulted 36\% of white colour globular shape somatic embryos like structures after 5 weeks. There was a significant difference $(\mathrm{P}<0.05)$ between $\mathrm{M} 1$ and M3 media. The least performance was recorded from M4 medium resulting green colour morphogenic response only. No significant difference $(\mathrm{P}<0.05)$ was observed between M3 and M4 media. [32] developed a cost effective basal medium for in vitro propagation of Anthurium as a replacement of MS medium using Albert's solution and stated that lower percentage of performance was noted from $5.0 \mathrm{mg} / 1$ concentration of Albert's solution due to toxic effects of the nutrients on embryo growth.

\section{Rhizome bud explants}

The result revealed that the different culture media used in this experiment had remarkable effect $(\mathrm{P}<0.0001)$ on the shoot bud formation in the top slice of the rhizome bud explants (Table 3 ). The top slices of the rhizome bud explants exhibited well (74.0\%) in M1 medium initiating yellowish white colour clump of shoot buds after 2 weeks of culture (Fig. 6A). However, there was a significant difference $(\mathrm{P}<0.05)$ between M1 and M2 media in performing shoot bud initiation. But M2 medium showed significantly higher $(\mathrm{P}<0.05)$ response compared to M3 and M4 media performing shoot buds after 2 weeks of culture. The finding is also supported by [32] who reported that number of shoot formations from MS medium was not remarkably varied with that from $5 \mathrm{ml} / 1$ concentration level Albert's medium.

Table 3. Shoot bud formation in the top slices of rhizome bud explants cultured in different media

\begin{tabular}{clc}
\hline Treatment code & \multicolumn{1}{c}{ Medium } & Shoot bud formation \% \\
\hline M1 & MS medium $+2.0 \mathrm{mg} / \mathrm{l} \mathrm{BAP}$ & $74.0 \pm 3.8^{\mathrm{a}}$ \\
M2 & $1.0 \mathrm{~g} / \mathrm{l} \mathrm{complex} \mathrm{fertilizer}+2.0 \mathrm{mg} / \mathrm{l} \mathrm{BAP}$ & $52.3 \pm 7.9^{\mathrm{b}}$ \\
M3 & $3.0 \mathrm{~g} / \mathrm{l} \mathrm{complex} \mathrm{fertilizer}+2.0 \mathrm{mg} / 1 \mathrm{BAP}$ & $31.0 \pm 5.9^{\mathrm{c}}$ \\
M4 & $5.0 \mathrm{~g} / \mathrm{l}$ complex fertilizer $+2.0 \mathrm{mg} / \mathrm{l} \mathrm{BAP}$ & $26.0 \pm 3.8^{\mathrm{c}}$ \\
\hline & F test & $\mathrm{P}<0.05$ \\
\hline
\end{tabular}

[Data based on the availability of surviving explants. Values represent means \pm standard error of the replicates. Means followed by the same letter in each column are not significantly different according to Duncan's Multiple Range Test at $5 \%$ significant level.] 


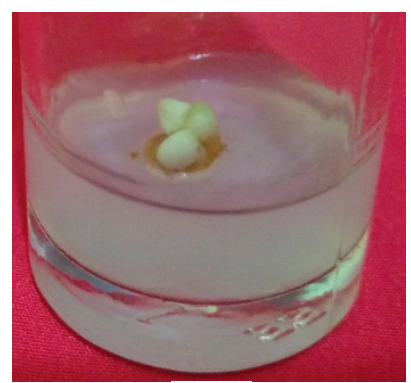

a

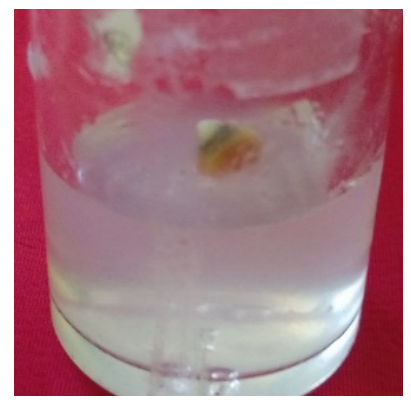

c

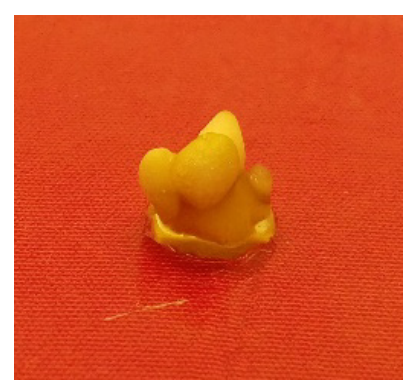

b

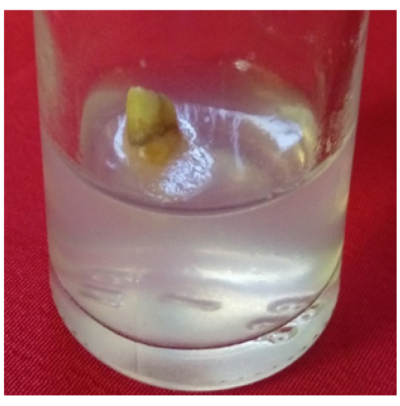

d

Figure 6. Morphogenic response of rhizome bud explants cultured in different media: Shoot bud formation of top slice of rhizome bud explants cultured on a) MS medium at $4^{\text {th }}$ week and b) at $6^{\text {th }}$ week, c) $1.0 \mathrm{~g} / \mathrm{l}$ Yara Mila complex, d) $3.0 \mathrm{~g} / 1$ Yara Mila complex at earlier stage

It was further noted that there was no any significant difference $(\mathrm{P}<0.05)$ between $\mathrm{M} 3$ and M4 media (Table 3) resulting least performance of $26.0 \%$ shoot bud initiation in M4 medium. This may be due to the higher amount of nutrients were detrimental for the response of cultured shoot buds. This is confirmed by [14] who used different strength of Hydro ${ }^{\circledR}$ Agri's fertilizer for plant regeneration and stated that higher rates of fertilizer is toxic to the tissues. Yara Mila complex fertilizer is able to supply all necessary macro and micronutrients and iron source for in vitro propagation of C. longa. [33] mentioned that percentage of sprouting was high on fertilizer medium as the fertilizer medium contains the macro elements $(\mathrm{N}, \mathrm{P}$ and $\mathrm{K})$ and other nutrients which are necessary for plantlet regeneration. Significant differences between MS medium and low-cost fertilizer medium were also observed by researchers [34-35].

\section{Cost analysis}

The total cost for 100 liters of substituted ingredients of MS medium was Rs.13,659 and the total cost of 100 liters of Yara Mila complex granular fertilizer $(1.0 \mathrm{~g} / 1)$ was only Rs.18.20. The use of Yara Mila complex granular fertilizer as an alternative source of macronutrients, micronutrients and iron source in MS media reduced the cost of those ingredients by $99.87 \%$ in the tissue culture of turmeric.

\section{Conclusion}

The results revealed that the aerial stem explants had relatively higher survival rate than rhizome bud explants. The vertical half of $1.0 \mathrm{~cm}$ long aerial stem explants showed higher survival rate of $58.7 \%$ with $28.3 \%$ morphogenic response. But vertical half of $0.5 \mathrm{~cm}$ long aerial stem explant responded well resulting $69.7 \%$ somatic embryogenetic response at 5 weeks of culture and it was the appropriate explant for somatic embryo formation among the aerial stem explants. And also top slice of the intact rhizome bud explant was the most responsive explant of rhizome buds performing $74.0 \%$ multiple shoot bud formation after 5 weeks of culture. Further, this study indicated that using $1.0 \mathrm{~g} / 1$ concentration of Yara Mila complex commercial fertilizer could be used as alternative nutrient source for MS medium for in vitro propagation of turmeric via somatic embryogenesis and organogenesis. 
Replacement of conventional macronutrients, micronutrients and iron source with locally available fertilizer reduced the cost of MS medium nutrients by $99.87 \%$. It could be concluded that it is possible to use locally available fertilizer like Yara Mila complex as a cost-effective alternative medium for in vitro propagation of turmeric.

\section{References}

[1] M. V. Shirgurkar, C. K. John, R. S. Nadgauda, Factors affecting in vitro microrhizome production in turmeric, Plant Cell, Tissue and Organ Culture. 64 (2001) pp. 5-11.

[2] T. H. Seran, In vitro propagation of ginger (Zingiber officinale Rosc.) through direct organogenesis: A Review, Pakistan Journal of Biological Sciences. 16(24) (2013) pp. 18261835.

[3] H. Sunitibala, M. Damayanti, G. J. Sharma, In vitro propagation and rhizome formation in Curcuma longa Linn, Cytobios-Cambridge. 105 (2001) pp. 71-82.

[4] T. Murashige, F. Skoog, A revised medium for rapid growth and bio assays with tobacco tissue cultures, Physiologia plantarum. 15(3) (1962) pp. 473-497.

[5] K. Nasirujjaman et al., Micropropagation of turmeric (Curcuma longa Linn.) through in vitro rhizome bud culture, Journal of Biological Sciences. 5(4) (2005) pp. 490-492.

[6] K. B. Kambaska, S. Santilata, Effect of plant growth regulator on micropropagation of ginger (Zingiber officinale Rosc.) cv - Suprava and Suruchi, Journal of Agricultural Technology. 5(2) (2009) pp. 271-280.

[7] S. Sathyagowri, T. H. Seran, In vitro plant regeneration of ginger (Zingiber officinale Rosc.) with emphasis on initial culture establishment, International Journal of Medicinal and Aromatic Plants. 1(3) (2011a) pp.195-202.

[8] S. Sathyagowri, T. H. Seran, Embryogenic response of aerial stem of ginger (Zinger officinale Rose.) cultured in different media, In: Proceeding of $12^{\text {th }}$ Annual Research Symposium, University of Kelaniya held on 3-4 November 2011. (2011b) pp. 152.

[9] K. K. Behera, D. Pani, S. Sahoo, Effect of plant growth regulator on in vitro multiplication of turmeric (Curcuma longa L. cv. Ranga), International Journal of Biological Technology. 1(1) (2010) pp. 16-23.

[10] A. Pandey, In vitro studies on turmeric (Curcuma), International Journal of Pharma Bio Sciences. 6(2) (2015) pp. 423-425.

[11] S. B. Babbar, R. Jain, Xanthan gum: an economical partial substitute for agar in microbial culture media, Current Microbiology. 52(4) (2006) pp. 287-292.

[12] V. A. Savangikar, Role of low cost options in tissue culture. In: Low cost options for tissue culture technology in developing countries, Proceedings of a technical meeting organized by the Joint FAO/IAEA Division of Nuclear techniques in food and agriculture., August 26-30, 2002, Vienna, IAEA. (2002) pp. 11-15.

[13] H. Sood, R.S. Chauhan, Development of low cost micropropagation technology for an endangered medicinal herb (Picrorhiza kurrooa) of north-western Himalayas, Journal of Plant Science. 4(2) (2009) pp. 21-31.

[14] M.A. Santana et al., A simple and low-cost strategy for micropropagation of cassava (Manihot esculenta Crantz), African Journal of Biotechnology. 8(16) (2009) pp.3789- 3897.

[15] N. M. Gitonga et al., Low technology tissue culture materials for initiation and multiplication of banana plants, African Crop Science Journal. 18(4) (2010) 243-251.

[16] S. Webster, S. Mitchell and M. Ahmad, A novel surface sterilization method for reducing microbial contamination of field grown medicinal explants intended for in vitro culture. Biotechnology Centre, UWI, Mona, Kingston. 7. 2003. 
[17] H. Smith, Phytochromes and light signal perception by plants: an emerging synthesis, Nature. 407 (2000) pp. 585-591.

[18] R. Zuraida, Improved in vitro propagation of Curcuma caesia, a valuable medicinal plant. Journal of Tropical Agriculture and Food Science, 41(2) (2013) pp. 273 -281.

[19] K. Lydiane, J. G. Kleyn, Plants from Test Tubes: An introduction to micropropagation, $3^{\text {rd }}$ ed., Timber press Inc., 1996, pp.82.

[20] J. Schulze, Improvements in cereal tissue culture by thidiazuron: a review, Fruit Vegetable and Cereal Science Biotechnology. 1(2) (2007) pp. 64-79.

[21] E. Vatankhah, V. Niknam, H. Ebrahimzadeh, Activity of antioxidant enzyme during in vitro organogenesis in Crocus sativus. Biologia Plantarum, 54(3) (2010) pp. 509-514.

[22] A. Lincy, B. Sasikumar, Enhanced adventitious shoot regeneration from aerial stem explants of ginger using TDZ and its histological studies, Turkish Journal of Botany. 34(1) (2010) pp. 21 29.

[23] E. V. Zapata et al., In vitro regeneration and acclimatization of plants of turmeric (Curcuma longa L.) in a hydroponic system, Biotechnology Application. 20 (2003) pp. 25-31.

[24] L. Lavakumaran, T. H. Seran, Effect of 6-benzyl-aminopurine and thidiazuron on in vitro shoot organogenesis of Aloe vera (L.) Burm. f. Chilean journal of agricultural research, 74(4) (2014) pp.497-501.

[25] M. Bhattacharya, A. K. Goyal, T. Mishra, In vitro regeneration of some lesser known medicinal Zingibers: a review, Biology of Useful Plants and Microbes. (2014).

[26] R. Raihana et al., In vitro Culture of Curcuma mangga from Rhizome Bud, Journal of Medicinal Plant Research. 5(28) (2011) pp. 6418-6422.

[27] P. S. Chougule et al., Microrhizome production in turmeric (Curcuma longa L.), Karnataka Journal of Agricultural Sciences. 24(4) (2011) pp. 493-496.

[28] G. Arghya, C. Padma, G, Prathadeb, A protocol for rapid propagation of genetically true to type Indian turmeric (Curcuma longa L.) through in vitro culture technique, Pelagia Research Library, Advances in Applied Science Research. 4(3) (2013) pp. 39-45.

[29] V. Gomathy, M. Anbazhagan, K. Arumugam, In vitro Propagation of Curcuma longa (Turmeric), International Journal of Research in Plant Science. 4(1) (2014) pp. 30-33.

[30] A. Das, V. Kesari, L. Rangan, Plant regeneration in Curcuma species and assessment of genetic stability of regenerated plants, Biologia Plantarum. 54 (2010) pp.423-429.

[31] S. Bandyopadhyay, J. D. Hamill, Ultra-structural studies of somatic embryos of Eucalyptus nitens and comparisons with zygotic embryos found in mature seeds. Annals of Botany, 86(2) (2000) pp. 237-244.

[32] K.M.C. Fernando, S. Subasinghe, Development of a cost-effective basal medium for in-vitro propagation of Anthurium (Anthurium andreanum) as an alternative for Murashige and Skoog (MS) medium, In Proceedings of 4th Academic Sessions, Academic Session. University of Ruhuna Sri Lanka. (2007) pp.61-65.

[33] R. Rhitu, “Genetics and plant breeding. National research centre on plant biotechnology”. Lal Bhadar Shastri Building. Pusa Campus. (2007) pp.42.

[34] K. Ogero et al., Low cost tissue culture technology in the regeneration of sweet potato (Ipomoea batatas (L) Lam). Research Journal of Biology. 2(2) (2012a) pp. 71-78.

[35] K. Ogero et al., Cost effective nutrient sources for tissue culture of cassava (Manihot esculenta Crantz). African Journal of Biotechnology. 11(66) (2012b) pp. 12964 - 12973. 